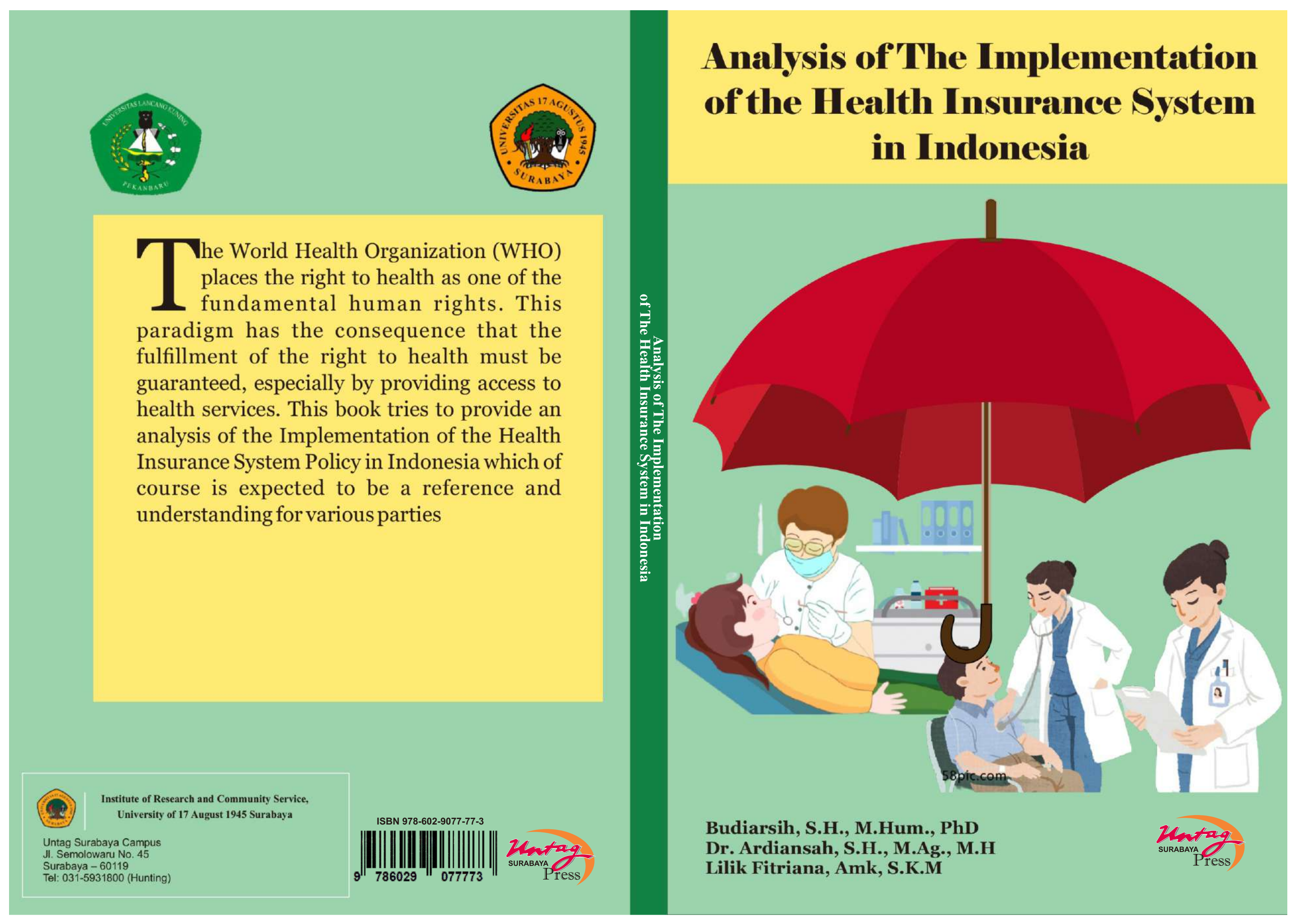




\section{Analysis of the Implementation of the Health Insurance System in Indonesia}

\section{AUTHOR:}

Budiarsih, S.H., M. Hum., PhD

Dr. Ardiansah, S.H., M.Ag., M.H

Lilik Fitriani Amk., S.K.M

\section{EDITOR \& LAYOUT:}

Sabila Wahyu Sagita

\section{PUBLISHER:}

Institute of Research and Community Service, University of 17 August 1945 Surabaya

Jl. Semolowaru 45 Surabaya

\section{Issue 1, August 2021}

Size: 15.5 x $23 \mathrm{~cm}$

Number of pages: iv +50 Pages.

\section{ISBN: 978-602-9077-77-3}

Copyright is protected by the Criminal Law, Articles 112-119, Law Number 28 of 2014 concerning Copyright. It is strictly forbidden to translate, photocopy, or reproduce part or all of the contents of the book without written permission from the publisher. 
This book is dedicated to:

The Unitary State of the Republic of Indonesia

17 August 1945 University Surabaya and Lancang Kuning

University Riau

LPPM University August 17, 1945

As Student Reference Material

Readers interested in Health Law 


\section{FOREWORD}

\section{Assalamualaikum Wr. Wb}

Alhamdulillah, with all the limitations, finally this scientific work was written in the form of a journal with the title "Analysis of the Implementation of the Health Insurance System Policy" can be completed by the author.

The author with all the limitations of knowledge and experience has made every effort to compile each sheet of this paper. However, the author realizes that the book is still not perfect and of course has shortcomings. For this reason, the author hopes for understanding and input from readers.

Finally, the author hopes that this paper can add to the horizons of thought for the readers.

Wabillahitaufik wal hidayah, wassalamu'alaikum Wr. Wb.

Surabaya, August 31, 2021

Author team 


\section{DAFTAR ISI}

TITLE PAGE

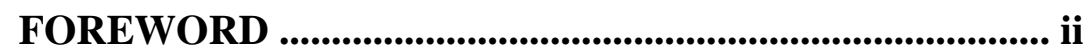

TABLE OF CONTENTS ..................................................... iii

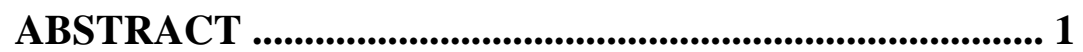

CHAPTER I INTRODUCTION

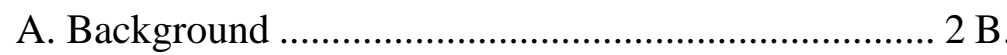

Problem Formulation ................................................ 7

C. The Purpose and Benefits of Writing ....................... 7

\section{CHAPTER II CONCEPT THEORY}

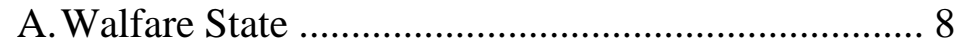

B. People's Right to Health Insurance ........................... 9

C. National Health Insurance (JKN) .......................... 13 D.

Conception of the Health Insurance System in

State of Law ........................................................ 20

E. Principles, Principles and Foundations of Guarantee Law Public Health ................................................... 28

CHAPTER III DISCUSSION

A. Analysis of Conception of Health Assurance Systemn …........................................................... 30

B. Analysis of Health Insurance Implementation Society based on Principles, Principles and Legal

Foundation ...................................................... 32

C. Analysis of National Health Insurance System Policy Implementation .................................................. 37

\section{CHAPTER IV}

A. Conclusion

45 B. Suggestion ............................................................... 46

REFERENCE ................................................................................ 47

iv 


\begin{abstract}
The state constitution of the 1945 Constitution mentioned that everyone has the right to live a prosperous life born and inward, residing, and getting a healthy and healthy living environment and entitled to health services. Under the Constitution and the Act, the Government makes efforts to ensure poor people's access to health service.

However, in its implementation, various problems cause pros and cons, especially related to financing mechanisms and systems. Although, the birth of the BPJS Law is certainly inseparable from the patent law, namely Law number 40 of 2004 concerning the National Social Security System.

For efforts to fulfill the rights of the community in the field of health that cannot be fully accommodated by the state, the government should evaluate the BPJS Law and Law No. 40 of 2004 on the National Social security system. The two laws currently implemented should be based on the 1945 Constitution and not harm the people.
\end{abstract}

Keywords: Implementation of Health Insurance System Policy 


\section{CHAPTER I}

\section{INTRODUCTION}

\section{A. Background}

In the development of the modern state today, the manifestation of government concern for its people must manifest it in two aspects, namely the context of justice and legality. The first context speaks to society's need for a sense of justice amid social dynamics and conflicts. And in the second context, concerns the so-called positive law, which is a rule established by the legitimate state authorities and in its enactment imposed in the name of the law (Murphy, 2008).

Such a conception of the state of the law is essential to realizing the purpose of the state, which is perfect happiness for man as individuals and social beings. Good law is a democratic law, which is based on the will of the people by the awareness of the laws of the people, while a fair law is a law that is appropriate and meets the purpose and purpose of every law, entering in the field of health.

The good cause of the state is all centered on the creation of the welfare of the people, and that welfare is the highest law for the state and state power (solus populi suprema lex). Thus, the purpose of the state of the law is the maintenance of order, security, and the maintenance of the general welfare in the broadest sense, 
including in the political, economic, social, and cultural aspects. This aspect of the purpose of the state by Charles E. Marriam is referred to as welfare staat (HRW, 1953).

In the Constitution of the Republic of Indonesia, the 1945 Constitution in Article 28H paragraph (1) outlines that "everyone has the right to live a prosperous life born in the inner clan, residing, and getting a healthy and healthy living environment and entitled to health services". Article 28H paragraph (3) of the 1945 Constitution affirms, "Everyone is entitled to social security that enables his or her full development as a dignified human being". In addition, Article 34 paragraph (3) of the 1945 Constitution also affirms that "the State is responsible for the supply of health care facilities and decent public service facilities". The mandate of the 1945 Constitution has been responded to by the Government together with the House of Representatives which has stipulated in Law No.36 of 2009 on Health and Law No. 40 of 2004 on the National Social Security System which includes health care guarantees.

In-Law Number 36 of 2009 concerning Health, it is stated that health is a human right and one of the elements of welfare that must be realized following the ideals of the Indonesian nation as referred to in Pancasila and the 1945 Constitution, everything that causes health problems to the Indonesian people. Will cause huge economic losses for the state, and every effort to improve the 
degree of public health also means investment for state development, and development efforts must be based on health insight in the sense that national development must pay attention to public health and is the responsibility of all parties, both the government and the community (Hsiao, 1995).

Based on the constitution and the law, the government makes efforts to ensure access of the poor to health services (Gostin \& Wiley, 2016), including the Health Social Safety Network Program (JPS-BK) in 1998-2000, the Energy Subsidy Reduction Impact Program (PDSE) in 2001, and the Compensation Program for Reducing Fuel Subsidy (PKPS-BBM) 2002-2004. In early 2005, through the Decree of the Minister of Health 1241/Menkes/XI/04 the government established the Poor Community Health Insurance (JPKMM) program through a third party, namely PT Askes (Persero). The Askeskin program is a continuation of the previously implemented PKPS-BBM, where the financing is funded from fuel subsidies which have been reduced by the government to be converted into subsidies in the health sector. The Askeskin program (2005-2007) then changed its name to the Community Health Insurance (Jamkesmas) program since 2008 until now. JPKMM/Askeskin, as well as Jamkesmas all, have the same goal, which is to guarantee health services for the poor and underprivileged using the principle of social health insurance. 
The implementation of the Jamkesmas program follows the implementation principles as regulated in the SJSN Law, namely nationally managed, non-profit, portable, transparent, efficient, and effective. The implementation of the Jamkesmas program is an effort to maintain continuity of health services for the poor and underprivileged, which is a transitional period until it is handed over to the Social Security Administering Body by the SJSN Law.

Health insurance as part of the social security system in Indonesia is indeed a form of social assistance program for health services for the poor and underprivileged (Bintang et al., 2019). This program is held nationally so that cross-subsidies occur to realize comprehensive health services for the poor (Magnussen et al., 2004; Outka, 1974). In essence, health services for the poor are the responsibility and are carried out jointly by the Central Government and Regional Governments. Provincial/Regency/City Governments are obliged to contribute to producing optimal services.

The health insurance program is administered nationally based on the principles of social insurance and equity (Chernichovsky, 1995; Meng et al., 2015). The goal is to provide health care benefits and protection in meeting basic health needs (Tangcharoensathien et al., 2011). The principle of social insurance includes mandatory and non-discriminatory participation, for formal groups, contributions based on a percentage of income become a shared 
burden between the employer and the recipient of the work, to a certain extent. So that there is a cooperation between the rich and poor, high-low risk of illness, young and old, with the same benefits of medical services (equity principle), comprehensive in nature, covering promotive, preventive, curative, and rehabilitative health services, including drugs and medical materials. Disposable.

Countries in the world through the international health agency WHO have agreed to achieve Universal Health Coverage (UHC) in 2014. UHC is a health system that ensures every citizen in the population has equitable access to promotive, preventive, curative, and rehabilitative health services (Maeda et al., 2014). Quality at an affordable cost which includes two core elements, namely access to fair and quality health services for every citizen, and protection of financial risks when citizens use health services where the country of Indonesia is currently in a transition period towards universal health service coverage (McIntyre et al., 2013; Organization, 2015).

The implementation of this national health insurance is certainly in line with what is mandated in Article 28H paragraph (3) regarding the right to social security and Article 34 paragraph (2) of the 1945 Constitution of the Republic of Indonesia, and the Decree of the People's Consultative Assembly of the Republic of Indonesia as stipulated in TAP No. X/MPR/2001, which assigned 
the President to establish a National Social Security System (SJSN) to provide comprehensive and integrated social protection.

\section{B. Problem Formulation}

Based on the background of the implementation of the national health insurance described above, the authors are interested in conducting an analysis of the study on the implementation of the National Social Security System (SJSN) policy to emphasize that whether the SJSN and BPJS programs have properly represented the manifestations of the welfare state? Therefore the authors set the title of this study as: "Analysis of the Implementation of the National Health Insurance policy."

\section{Purpose and Benefits of Writing \\ 1. Purpose of Writing}

The purpose of this study is to analyze the implementation of the National Social Security System (SJSN) and BPJS policies that are currently being implemented as well as various problems that occur related to the implementation of these policies.

\section{Benefits}

This paper is expected to provide benefits for all parties in implementing the National Health Insurance policy. 


\section{CHAPTER II}

\section{THEORY CONCEPT}

\section{A. Welfare State}

The concept of state welfare does not only include a description of a way of organizing welfare or social services (Aravacik, 2018; Lönnqvist \& Laihonen, 2012). But it is also a normative concept or ideal approach system which emphasizes that everyone must obtain social services as their right. The welfare of the state is also the biological child of ideological and theoretical struggles, especially those with a left-wing view, such as Marxism, Socialism, and Social Democracy. However, and this is interesting, the concept of state welfare thrives in democratic and capitalist countries, not in socialist countries.

In Western countries, state welfare is often seen as a strategy of "antidote" to capitalism, namely the negative impact of a free market economy (Korpi, 2001). Therefore, the welfare state is often referred to as a form of "compassionate capitalism". As an illustration, Thoenes defines the welfare state as "a form of society characterized by a system of democratic government-sponsored welfare placed on a new footing and offering a guarantee of collective social care to its citizens, concurrently with the maintenance of a capitalist system of production. " Although with a different model, capitalist and democratic countries such as 
Western Europe, the US, Australia, and New Zealand are some examples of adherents of the welfare state. Meanwhile, countries in the former Soviet Union and the Eastern Bloc generally do not adhere to the welfare state, because they are neither democratic nor capitalist.

\section{B. Community's Right to Health Insurance}

Health is a basic need for every human being (de Campos, 2012) . Without health, humans will lose their productivity and lose their ability to live and enjoy life. Thus, declining health status is tantamount to a decrease in the quality of life itself. Therefore, it is not an exaggeration if many people believe that real wealth is healthy.

Given such a value (health as a basic need), the right to health is a fundamental right for humans. The world organization that deals with health issues, the World Health Organization (WHO), places the right to health as one of the fundamental human rights. This paradigm has the consequence that the fulfillment of the right to health must be guaranteed, especially by providing access to health services (Ruger, 2004).

In this regard, to ensure that every human being is guaranteed health or to realize universal health, WHO has launched a program known as Universal Health Coverage (UHC). UHC is a program that ensures that people have access to health services without 
having to face financial hardship. It is further explained on the WHO website that ease of access is also accompanied by maintaining the quality of health services.7 This program is in full accordance with the principles stipulated in the Universal Declaration of Human Rights (UDHR) 1948.

Health insurance is a constitutional right of every citizen, by having this health insurance every citizen has the right to get health services. This guarantee is regulated in Article $28 \mathrm{H}$ paragraph (1) of the 1945 Constitution of the Republic of Indonesia (UUD NRI 1945), which stipulates that everyone has the right to live in physical and spiritual prosperity, to have a place to live, and to have a good and healthy living environment and entitled to health services.

The Government of Indonesia through the Ministry of Health since January 1, 2014, has organized health insurance for the community through the Social Security Administering Body (BPJS) which has organized Health Insurance. Thus the government is obliged to provide quality health services. Health services are human rights that must be fulfilled by the government, this is stated in Law Number 36 of 2009 concerning Health Article 15 which states that:

"The government is responsible for the availability of the environment, arrangement, health facilities, both physical and social for the community to achieve the highest degree of health". 
Health Law Number 36 of 2009 has opened a new paradigm for the scope of health. Health is welfare and safety that includes physical, mental, and spiritual as well as social, which in the end becomes the main driving force for everyone to live productively in social and economic terms. Previously, MPR Decree No. XVII/MPRRI/1998 and Law No. 39/1999 on Human Rights have further strengthened this paradigm shift. At least the position of the TAP MPR is higher than the Law has emphasized that health matters are contained in two main chapters, namely those related to the right to self-development in Chapter III, and the Right to Welfare in Chapter VIII.

"Right to Welfare" Article 27: Everyone has the right to live in physical and spiritual prosperity. Article 28: Everyone has the right to a good and healthy environment. Article 29: Everyone has the right to live and live a decent life. Article 30: Everyone has the right to get special facilities and treatment in childhood, in old age, and if he has a disability.

Health insurance is a relationship where the state acts as a guarantor and citizens as a guaranteed party. To obtain this guarantee, citizens are obliged to provide material engagements by paying a fee. So the state also issued various laws and regulations to carry out the obligations of the state. The legal document is the basis for a very general understanding of health, where health is a state of well-being of body, soul, and society that enables everyone 
to live socially and economically productive lives. The health services referred to by the 1945 Constitution are health care, including efforts to overcome and prevent health problems that require examination, treatment, and/or care.

The legal basis and basis of the National Health Insurance (JKN) itself is contained in Law No. 24 of 2011 concerning the Social Security Administering Body (BPJS) and Law No. 40 of 2004 concerning the National Social Security System (SJSN). In addition, the policy of the National Health Insurance (JKN) program has also been regulated in the Minister of Health Regulation No. 71 of 2013. The Regulation of the Minister of Health No. 71 of 2013 contains about how the general provisions of the National Health Insurance (JKN) program are regulated in article 1, the provision of health services in article 2 and article 3 , cooperation of health facilities with the Social Security Administering Body (BPJS) Health in article 4 to article 12, health services for participants in the National Health Insurance (JKN) program in articles 13 to 31 , payment systems for health services in article 32, quality control and cost control in articles 33 to 38 , reporting and utilization review in article 39, transitional provisions in article 40 and article 41 , as well as the closing provisions in article 42 and article 43

Thus, the National Health Insurance (JKN) developed in Indonesia is part of the National Social Security System (SJSN). 
The National Social Security System is implemented through a mandatory (mandatory) Social Health Insurance mechanism based on Law No. 40 of 2004 concerning the National Social Security System (SJSN). The aim is that all Indonesians are protected under the insurance system so that they can meet the basic needs of proper public health. The National Health Insurance Policy (JKN) is divided into two membership or target groups, namely, workers who work for state administrators including prospective civil servants, civil servants, members of the TNI, members of the National Police, state officials, non-civil servant government employees, student soldiers. TNI, and Police students. While the second is workers in private business entities or not government employees. To meet the health service needs of participants in the National Health Insurance (JKN) program, it is necessary to have health service providers.

\section{National Health Insurance (JKN)}

Health insurance is a form of social protection organized by the state to ensure its citizens meet the basic needs of a decent life. The health insurance program is a government and community program whose aim is to provide comprehensive health insurance for every Indonesian so that the Indonesian population can live a healthy, productive, and prosperous life. 
Health insurance is a guarantee of health protection so that participants obtain health care benefits and protection in meeting basic health needs that are given to everyone who has paid contributions or whose contributions are paid by the government. Health insurance is an individual health service, covering promotive, preventive, curative, rehabilitative services, drug services, consumable medical supplies by the necessary medical indications.

The implementation of the National Health Insurance (JKN) program, which is intended to achieve equitable access for all Indonesians, is not without problems. Apart from its usefulness, the implementation of social security programs, especially JKN in the BPJS era, was questioned by several people. There are various aspects in question, one of which is the regulation that supports the implementation of JKN, in particular Law Number 24 of 2011 concerning the Social Security Administering Body (UU BPJS 2011). This can be seen from the rise of judicial review lawsuits against the law.

The implementation of Health Insurance is carried out by 4 (four) main actors, namely Participants, the Health Social Security Administering Body (BPJS), Health Facilities, and the Government. 


\section{1) Health Insurance Participants}

Health Insurance participants are everyone, including foreigners who have worked in Indonesia for at least 6 (six) months, who have paid contributions. Participants are entitled to Health Insurance benefits. To continue to receive health care insurance, participants are required to pay health insurance contributions regularly and continuously until the end of life. Health insurance participants are divided into two main groups, namely Contribution Assistance Recipients and Non-Contribution Assistance Recipients. Contribution Assistance Recipients receive a contribution subsidy from the Government. Non-Recipients of Contribution Assistance are required to pay Health Insurance contributions by themselves or together with their employers. Hasbullah Thabrany, N Health Insurance

2) BPJS Health

BPJS Health is a legal entity formed to administer the health social security program. BPJS Health was formed by Law no. 40 of 2004 concerning the National Social Security System and Law no. 24 of 2011 concerning BPJS. These two laws regulate the dissolution of PT Askes Persero and the transformation of PT Askes Persero into BPJS Health. The dissolution of PT Askes Persero is carried out without a liquidation process and is carried out by transferring the assets and liabilities, rights and legal obligations of PT Askes Persero into assets and liabilities, legal 
rights and obligations of BPJS Health all employees of PT Askes Persero to become employees of BPJS Health.

3) Health Facilities

BPJS Health builds a network of health facilities by collaborating with government-owned or private health facilities to provide health services for Health Insurance participants and their families. This network of health facilities is divided into three main groups, namely first-level health facilities, advanced health facilities, and supporting health facilities.

First-level health facilities provide non-specialist health services, while advanced-level health facilities provide specialist and sub-specialist health services. Supporting health facilities serve drug, optical, and other medical support services.

4) Government

The government plays a role in determining policies (regulators), fostering and supervising the implementation of health insurance programs.

a. Regulator

Those who act as regulators are the National Social Security Council (DJSN), the central government, and local governments.

DJSN is an executive support agency established by Law no. 40 of 2004 to organize SJSN. DSJN is responsible to the President. DSJN has the function of formulating general policies and synchronizing the implementation of SJSN. DSJN is tasked with 
conducting studies and research, proposing investment policies for social security funds, proposing a social security budget for recipients of contribution assistance, and supervising BPJS.

The central government which is directly involved in the delivery of health services is the Ministry of Health. The Ministry of Health regulates various technical matters in the implementation of Health Insurance, including health service procedures, health facility standards, service tariff standards, drug formularies, and health facility associations.

Local governments regulate the implementation of Health Insurance in their administrative areas. Based on Law no. 23 of 2014 concerning local governments, local governments are obliged to build a national social security system. This obligation is implemented, among others, by ensuring the availability of health facilities, participating in subsidizing health insurance contributions, supervising the implementation of health insurance in its working area, building public support for health insurance.

b. Supervisor

DSJN has the authority to monitor and evaluate SJSN. The BPJS Law stipulates that the external supervisors of BPJS are the DSJN, the Financial Services Authority (OJK), and the Supreme Audit Agency (BPK).The procedures for health services in the Health Insurance program are as follows: 
1) Health services are carried out in a structured and tiered manner by requiring participants to obtain health services at the first level health facility where the participant is registered if there is a medical indication the participant has the right to be referred to the nearest advanced facility following the referral system.

2) For the first time, each participant is registered by BPJS Health at a first-level health facility determined by BPJS Health after receiving a recommendation from the local district/city Health Office. After at least the next three months, Participants have the right to choose the first level of health facilities they want.

3) Health services are provided at government-owned or private health facilities that collaborate with BPJS.

4) Emergency health services can be provided at any health facility, including health facilities that do not cooperate with BPJS.

5) Participants who receive emergency services at health facilities that do not cooperate with BPJS Health, must immediately be referred to a health facility that cooperates with BPJS health after the emergency is resolved and the patient is in a condition that can be transferred.

6) Inpatient services in hospitals are provided in standard classes and treatment rooms are provided based on the number of contributions paid. 
7) The Health Insurance Program is required to provide compensation to meet the medical needs of participants in areas where there are no health facilities that meet the requirements. Compensation is given in cash.

8) The Health Insurance Program guarantees medicines and medical consumables by considering medical needs, availability, effectiveness, and efficiency of medicines or medical consumables by referring to the list and prices of medicines and medical consumables in the National Formulary, as well as the Compendium of Medical Devices. , which is determined by the Minister of Health.

9) The Health Insurance Program guarantees the service of medicines that are by medical indications but are not available in the National Formulation, by advanced health facilities based on the approval of the Medical Committee and the head/director of the hospital.

10) The Health Insurance Program guarantees ambulance services for the transformation of referral patients between health facilities in collaboration with BPJS Health, which is accompanied by efforts to maintain patient safety. In emergency conditions, ambulance services can be provided for referrals to health facilities that do not cooperate with BPJS Kesehatan to save the patient's life. 
11) In developing health services, BPJS Kesehatan applies a quality control system, a cost control system, and a payment system to improve the effectiveness and efficiency of health insurance and to prevent misuse of health services.

12) For the type of service that can lead to abuse of service, participants are charged a cost reduction.

13) The referral program is organized by the first-level health facility on the recommendation or referral of a specialist or subspecialist doctor for participants with chronic diseases whose condition is stable and still requires treatment or longterm care. Currently, the referral program is limited to cases of hypertension and type 2 diabetes mellitus

D. Conception of the Health Insurance System in the State of Law

Although in Indonesia, the concept of public health insurance is still an integral part of other social security systems and does not stand alone (Ron et al., 1990). However, advancing public welfare in the Indonesian context has become the ideals formulated by the nation's founders. The welfare that is expected and will be built is of course a social justice society, which is built based on cooperation and togetherness. Such a prosperous society, of course, can only be built by humans who have a national identity, by what is contained in Pancasila. 
This line of thinking is important, because every human being needs the fulfillment of social needs, even at the extreme, it can be said that service cannot be separated from human life, especially in the health sector. Society at all times will always demand the fulfillment of quality social needs from bureaucrats, although these demands are often not following what is expected, because empirically the fulfillment of social needs, which has occurred so far, displays the characteristics of being convoluted, slow, expensive, and tiring. Such a tendency occurs because the community is still positioned as the party who "serves" not the one who is "served." Therefore, it is necessary to realize the correct paradigm in Indonesia, so that the ideals of the rule of law are interpreted at the correct level.

Osborne and Plasterik characterize the government as expected above as a government-owned by the people, namely a government that transfers its control authority to the community. The community is empowered so that they can control the fulfillment of social needs, which are provided by the government. With the control of the community, public services will be better because they have a better commitment, are more caring, and are more creative in solving problems. Of course, the services provided must be interpreted as a government obligation, not a right, thus the fulfillment provided will be responsive to the needs of the community. 
Meanwhile, according to Kotler, fulfillment of needs is any activity that is profitable in a group or entity and offers satisfaction even though the results are not in a physical product. This formulation is nothing but a form of state administration for its people to meet the needs of the community itself and has the aim of improving the welfare of the community. In this regard, the fulfillment of public health insurance is present in Indonesia.

Theoretically, the purpose of meeting social needs, including health insurance, is basically to provide satisfaction to the community (Locker \& Dunt, 1978). To realize the goal of this service, a legal state administrator must be reflected in various aspects of meeting public needs, namely:

a. Transparency, namely compliance that is open, easy, accessible to all parties in need, provided adequately, and is easy to understand;

b. Accountability, namely compliance that can be accounted for following the provisions of the legislation;

c. Conditional, namely compliance with the conditions and capabilities of service providers and recipients while adhering to the principles of efficiency and effectiveness;

d. Participatory, namely fulfillment that can encourage community participation in the implementation of public services by taking into account the aspirations, needs, and expectations of the community; 
e. Equality of rights, namely the fulfillment of nondiscrimination seen from any aspect, especially ethnicity, race, religion, class, social status, and others;

f. The balance of rights and obligations, namely the fulfillment of which considers the aspect of justice between the provider and the recipient of the service.

The realization of the purpose of public guarantees is also reflected in the Indonesian constitution, the 1945 Constitution, both in the Preamble and in several of the Articles, which have provided a strong normative legal basis, although they do not explicitly mention social (health) protection and security. For example, in Article 27 Paragraph 2 of the Post-Amendment 1945 Constitution, it is stated that "Every citizen has the right to work and a decent living for humanity."

This mandate was later confirmed through a more specific Article, namely Article 34 Paragraph 2 of the Amendment to the 1945 Constitution of 2002 which states that "The state shall develop a social security system for all the people..."

The term social security is already very popular. However, the implementation of the social security program itself is often understood differently. In the social security system, the benefits provided must meet certain criteria that with these benefits, people will have a sense of security, from birth to death. If these criteria 
are not met, the intended social security program is social assistance or social services or other temporary social protection, following social events in the community, including limitations in accessing health services, famine, and natural disasters, and so on. With such a perception, it is not surprising that in Indonesia the new social security system was started in 1968 and 1976 through health insurance and Jamsostek. Compare this with Malaysia which has started in 1959 through the EPF (Employee Provident Fund) program (Sheikh Hussin, 2012).

This means the social security system is a collection of interrelated programs to provide social protection or a sense of security (Devereux \& Sabates-Wheeler, 2004). This sense of security can be realized if humans can be guaranteed from various threats, both those that come suddenly (eg illness or accident) or natural ones (eg retirement), which can have an impact on their economic and social capabilities.

Several other articles in the 1945 Constitution also emphasize the importance of a decent life for citizens, as an implication of the obligation to social security for citizens, for example, Article 27 paragraph 2 which states that, "Every citizen has the right to work and a decent living for humanity. ." or Article 31 paragraph 1, that "Every citizen has the right to education." and Article 34 paragraph 1, which states that, "The poor and neglected children are cared for by the state". 
In addition to the 1945 Constitution, in the MPR RI Decree No. X/MPR/2001 concerning the Report on the Implementation of the Decisions of the MPR RI by State High Institutions at the 2001 MPR RI Annual Session related to social protection and security has also assigned the President of the Republic of Indonesia to establish a national social security system to provide more comprehensive social protection. and integrated with the Indonesian people.

Several years ago, a National Social Security System Team (SJSN Team) was also formed based on the Decree of the President of the Republic of Indonesia No. 20 of 2002 dated April 10, 2002, concerning the Establishment of the National Social Security System Team. The team has also succeeded in drafting a Bill (RUU) on the National Social Security System. The SJSN team consists of representatives from various government agencies, NGOs, and experts in their fields. And based on their duties, the person in charge of the SJSN Team is divided into 4 groups, namely: Substance, Institutional, Mechanism/Budget, and Establishment of the Social Security Program. The National Social Security System to be built is based on the concept of social insurance, and is based on the principle of cooperation through a collection of contributions and managed through a social insurance mechanism. Its implementation is regulated by law and implemented gradually following the development and capacity of 
the National economy as well as the ease of recruitment and collection of contributions regularly. The Social Security Law that was born from this team, in essence, becomes an umbrella for a National Social Security System (Social Security) that is suitable for Indonesia in the future which includes social insurance and social assistance.

Another basis for consideration is the ILO Convention No. 102 of 1952 which also recommended that all countries in the world provide basic protection to every citizen to fulfill the United Nations Declaration on Social Security Rights.

The experience of various countries shows that social protection and security held by the government together with the community at the national level (Barrientos \& Hulme, 2009), in addition to providing social protection and security for the entire community, also helps to drive the wheels of development. Based on the facts that have occurred in the last few years, it also proves that social protection and security are increasingly needed when global and national economic conditions are experiencing various crises (multi-dimensional crises), thus threatening people's welfare. For this reason, one of the efforts to save from these various risks is the need to develop a comprehensive and integrated social protection and security system, so that it can provide optimal benefits for all its citizens. 
The definition of social protection and security contained in the national development plan is defined as "...a policy step is taken to provide protection and a sense of security for the poor, especially the poorest and the poorest. )."

Meanwhile, according to $\mathrm{ADB}$, the definition of social protection and security is as follows, "the set of policies and programs designed to promote efficient and effective labor markets, protect individuals from the risks inherent in earning a living either from small-scale agriculture or the labor market, and provides a floor of support to individuals when market-based approaches for supporting themselves fail".

From this definition, it is emphasized that social protection and security, including health, are closely related to the problem of poverty, which in turn has an impact on the decline in the quality of human life as a whole. For this reason, to support the government's efforts to provide/create social protection and security, especially in the field of health that is more complete to every citizen, the government needs to reorganize the various forms of protection and social security that already exist, and make it a system of protection and security. A more comprehensive social and provide more optimal efficiency and effectiveness. 


\section{E. Principles, Principles and Legal Basis of Public Health Insurance}

Based on the experience of various developed countries, several principles can be used as a reflection in the process of implementing the social security system, including; First, the social security program grows and develops in line with the economic growth of a country. This is related to the increasing needs of the community, in line with the increasing demands in the welfare sector. The need in the workforce/formal group environment always grows earlier. Therefore, the social security program develops first informal groups, and then in non-formal groups.

Second, there is a role for participants to finance the social security program, through insurance mechanisms, either social/commercial or savings. This is even though the burden of contributions can be the burden of the employer and recipient of work (for formal workers), from state subsidies in the form of social assistance (for the poor) and the participants themselves for independent and well-off groups.

Third, participation is mandatory so that the law of large numbers is quickly fulfilled. This is very important in the survival of the program. A large number of participants will have an impact on the ability to provide benefits/benefits packages and the certainty of actuarial calculations. 
Fourth, the large role of the state, both in regulations, policies, and the implementation of social security programs. This is a mandatory membership risk. Even the state is obliged to guarantee the viability of the social security program, including providing subsidies if necessary or guaranteeing the security and added value of investment results. Fifth, it is not for profit, all added value from the investment must be returned to increase social security program guarantees.

Sixth, the implementation of the social security program must be carried out with full prudence, transparency, accountability, considering a large number of needs and the nature of the social security program that must be sustainable. Therefore, its implementation must be based on the law.

\section{CHAPTER III}

\section{DISCUSSION}

The main problem with access to health services in Indonesia is the issue of poverty, especially poverty caused by structural factors. Because of the unequal economic income as well as the very sharp gap between citizens, resulting in each citizen getting different economic services based on ownership of the property to pay for health costs. Such conditions are increasingly formed when the state also participates in making the same choice, namely the 
commercialization of health programs through grouping services based on the financial value borne by the people.

\section{A. Conceptual Analysis of the Health Insurance System}

Over time, and to maintain public health status within the limited health financing as described above, several concepts and systems of protection and social security in the health sector have been designed, namely:

a. Social solidarity-based financing, in the form of Jamkesnas. Jamkesnas is a form of prepaid health insurance that is mandatory for all people to meet the main health needs of every citizen.

b. Voluntary-based financing, in the form of commercial health insurance (askes) - based on Law no. 2 of 1992 concerning Insurance Business; and the voluntary Community Health Maintenance Insurance (JPKM) - based on Law no. 23 of 2009 concerning Health and WHO Constitution.

c. Health financing for the informal sector, in the form of micro health insurance - from by and for the community, for example in the form of a Health Fund; and community social funds collected for basic social services, including health, for example, collected from religious social funds from all religions (collections, paramita funds, infaq, etc.). 
d. Health financing for poor families with insurance principles, in the form of premium financing by the government for JPKGakin.

In addition to the four forms above, there is social security in the health sector, namely Health Insurance organized by PT Askes. Askes provides health services following applicable regulations.

In practice, this policy seems to run in a dilema. On the one hand, public health problems are increasingly complex, on the other hand, the health efforts implemented by the government have not fully met the needs of the community. Meanwhile, public health care insurance is expected to reduce the burden on the community to obtain quality health services.

Meanwhile, based on the results of the 2002 MPR-RI Annual Session, regarding health, it was stated that they had confirmed the formulation, namely:

1. Strive to increase the health budget gradually until it reaches a minimum amount of $15 \%$ following the state's financial condition from the APBN/APBD, as determined by WHO.

2. Continuing the emergency program of basic health services for poor families, vulnerable to nutrition, especially for infants, toddlers, pregnant women, and postpartum mothers.

3. Realizing a public health care insurance system.

4. Establish post-conflict trauma recovery centers, especially in refugee areas 
B. Analysis of the Implementation of Public Health Insurance based on Principles, Principles and Legal Basis

If you depart with the basis of the argument that the implementation of social security in Indonesia so far, it can be said to be a dilemma and less successful. The problem is the result of several main problems, namely;

First, there is no certainty of social protection and security for every citizen (WNI) to fulfill their daily needs as mandated in the amendment to the 1945 Constitution of 2002, Article 34 paragraph 2, namely "The State shall develop a Social Security System for all people". The current protection and social security have not been able to cover all Indonesian citizens. For example, there is no social protection and security for informal sector workers.

Second, is the lack of clarity on a single statutory regulation that underlies the implementation of the social protection and security system. Each type of social protection and security currently available is based on different laws and/or regulations. This in turn will cause the handling of existing social protection and security schemes to be fragmentary and even overlapping. For example - health insurance - covered by PT. Jamsostek, PT Askes, and Community Health Maintenance Insurance (JPKM). And the last is that the existing social protection and security schemes are 
still limited, so the benefits (quantity and quality) obtained are also still limited.

Moreover, in the various laws and regulations that exist in Indonesia today, there are many definitions/definitions of social protection and security. For example in Law no. 6 of 1974 concerning the Basic Provisions of Social Welfare, it is stated that; "Social security as an embodiment of social security is the entire system of protection and maintenance of social welfare for citizens organized by the Government and/or the community to maintain the level of social welfare."

Meanwhile, in Law no. 2 of 1992 concerning Insurance Business, it is stated that; "Social Insurance Program is an insurance program that is held obligatory based on a law, intending to provide basic protection for the welfare of the community."

Furthermore, the problem that also arises is that the current legal basis for social protection and security is still partial and not yet integrated. Although the Preamble to the 1945 Constitution, and several articles contained therein, for example, Article 27 (2), Article 31 (1), Article 34 (1), and Article 34 (2) of the amendments to the 1945 Constitution on August 10, 2002, are the legal basis for the implementation of the Social Protection and Security System (SPJS), however, the legal basis for the operational implementation of all social protection and security schemes is still different. For example, social security in the field of labor is based 
on Law no. 3 of 1992 concerning Workers' Social Security which includes Insurance for Old Age, Death, Work Accidents, and Health Care for private employees, through PT. Social Security. Meanwhile, health insurance for civil servants through PT Askes is based on Law no. 2 of 1992 and PP No. 69 of 1991. Furthermore, old age and pension benefits for civil servants through PT Taspen are based on Law no. 43 of 1999; and for the TNI/Polri through PT Asabri based on Law no. 6 of 1966.

The existence of various legal products, resulting in many institutions implementing social protection and security. This is contrary to the law of the large number, namely with a large coverage (participants), the risk distribution will be more evenly distributed and the burden borne by each participant (premium) will be smaller.

Social security should be intended for all Indonesian citizens following the rights of citizens and human rights (Ackerman, 2005; Suryawati, 2020). However, there is an idea that with the limitations of state finances, then: (1) social insurance is intended for all Indonesian citizens, while (2) social assistance is only for groups in need (eg the poor, vulnerable, and disaster victims).

Currently, health services are getting more and more expensive. The high health costs that must be incurred by individuals, causing not all members of the community to be able to obtain proper health services (Etienne et al., 2010). In addition, 
the government's ability to subsidize health services is very low. Without a system that guarantees health financing, more and more poor people will not get the health services they need.

With the tendency to increase the cost of living, including the cost of health care, it is estimated that the burden on the community, especially the low-income population, will increase. Increased health costs will make it difficult for the community to access the health services they need, especially if the financing must be borne out of pocket in the fee for services system.

The fee for service system for the health care system makes it difficult for the community to access proper health services. However, if you want to take insurance, not many people can afford to pay the premium. For example, in 1995, the cost of hospitalization for a patient in a hospital for five days consumed 1.4 times the average monthly income of DKI Jakarta residents. In 1998 this fee jumped to 2.7 times. If these costs are not covered by the office or insurance, it means that the person's household costs will be sucked up to pay for hospital treatment. The question is how and what happens to the poor when they are sick, while health care costs are increasing over time.

In this regard, it is important to develop community empowerment and local institutions, for example through tax incentives. For example, empowering zakat, infaq, and sodaqoh (Islam), tithing (Christian), and dharma (Hinduism), so that zakat, 
tithe, and dharma payers do not need to be subject to income tax. In addition, forms of local wisdom that already exist and develop in the community need to be strengthened. For example Banjar in Gianyar Regency, Bali - which is closely linked to traditional villages - through health fund contributions to help indigenous villagers who are sick; Maternal Maternity Savings (Tabulin) in Banyumas Regency, Central Java - through a savings system for health funds, especially for the cost of childbirth when the mother gives birth; Adoptive Father in Gianyar Regency, Bali - in the form of mutual benefits between entrepreneurs (in the form of ease of licensing and internet facilities) and students from poor families (in the form of skills/craft training); contract doctors in Gianyar Regency, Bali - in the form of compulsory health contributions paid by Muslim community groups to private doctors using a contract system.

Based on Law No. 40 of 2004 concerning the National Social Security System, Article 2 states that the national social security system is implemented based on the principle of humanity, the principle of benefit, and the principle of social justice for all Indonesian people. Furthermore, Article 3 states that the national social security system aims to guarantee the fulfillment of the basic needs of a decent life for every participant and or member of his family. As well as in Article 4 it is stated that the social security system is implemented based on the principles of cooperation, non- 
profit, openness, prudence, accountability, portability, mandatory participation, mandated funds, and the results of the management of social security funds are used entirely for program development and an amount of Rp. - the magnitude of the interests of the participants.

C. Analysis of National Health Insurance System Policy Implementation

A prominent philosopher, Plato revealed that the state was formed by and intended for humans. The state's welfare for its people is a must. Similarly, Aristotle said that the purpose of the formation of the state is for the good of all the people. This also applies in Indonesia, as outlined by the Founding Fathers as mandated in the Preamble and the 1945 Constitution. Currently in Indonesia, the fulfillment of all social security is left to the market mechanism through 4 (four) BPJS in the form of a Limited Liability Company (PT) ), namely Jamsostek, Askes, Taspen, and Asabri which are owned by the state (BUMN)

Referring to Law no. 19 of 2003 concerning BUMN and Law no. 40 of 2007 concerning Limited Liability Companies (PT), the existence of BUMN and PT is for profit. Meanwhile, based on Law No. 24 of 2011 concerning BPJS, philosophically, the objectives, management structure, and types of BPJS products as a legal entity for administering social security should not seek profit. The SJSN 
Law has ordered the correction of the misuse of the market instrument.

The concept of social security promoted by BPJS is also different from the Public Health Insurance Program (Jamkesmas). Jamkesmas funds are distributed according to the quota set, do not return to the state treasury (consumable), and are limited to the criteria for the poor. While BPJS uses an insurance system, the target is for all Indonesian citizens (universal coverage), even the accumulated funds can be used as state foreign exchange reserves.

According to Thabrany, in formulating the concept of social security in Indonesia, what must also be understood is the existence of three main pillars of security, namely: sufficient to meet the basic needs of a decent life. In practice, this social assistance is realized through contributions from the government so that those who are poor and can't afford to continue to be SJSN participants.

The second pillar is the social insurance pillar which is an insurance system that must be followed for all residents who have income (above the poverty line) by paying contributions that are proportional to their income/wages. Pillar one and pillar two are the foundation of the National Social Security System to fulfill the basic needs of a decent life that must be followed and accepted by all people (the pillar of public social security). The third pillar is an additional pillar or supplement for those who want a guarantee that is greater than the guarantee for a decent standard of living and 
those who can afford the guarantee (private/private insurance pillar on a voluntary/trade basis). This pillar can be filled by buying commercial insurance (whether health insurance, pension, or life insurance), personal savings, or other programs that can be carried out by individuals or groups such as investing in stocks, mutual funds, or buying property as savings for themselves or his family. In the third pillar of welfare guarantees, what will be fulfilled is a desire (want, demand) while in the first two pillars what will be fulfilled is a need (need).

Starting from the arguments above, the reasons for the establishment of the BPJS Law are 1). As the implementation of Law no. 40 of 2004 after the Constitutional Court's Decision on Case Number 007/PUU-III/2005; 2). To provide legal certainty for BPJS in implementing social security programs based on Law no. 40 of 2004; 3). As a legal basis for the establishment of a regionallevel BPJS which can be established by local regulations by complying with the provisions on the national social security system as regulated in Law no. 40 of 2004; 4). To improve the performance of BPJS at the national level and its sub-systems at the regional level through clear regulations regarding the main tasks, functions, effective organization, implementation mechanisms following the principles of good governance, supervisory mechanisms, handling transition periods and 
requirements to be able to form regional BPJS or management of comprehensive health insurance in the regions.

With the stipulation of BPJS, two anomalies in the implementation of Indonesian social security which are contrary to universal principles of social security in the world will be terminated. First, the State no longer collects profits from the mandatory State contributions collected by its business entities, but in the future, the State is responsible for fulfilling the people's constitutional rights to social security. Second, Indonesia's social security has officially moved from being administered by a private body to being managed by a public agency.

In principle, the BPJS trial has been implemented since 2012 but has only been formally implemented since January 1, 2014, in all health services in Indonesia. Evaluation of the running of the National Health Insurance is planned every year with a period of six months with annual periodic reviews of health facility eligibility, credentialing, service quality, and adjustments to the amount of payment of economic prices. It is hoped that by 2021 there will be a sufficient number of health facilities and health workers, equitable distribution, optimal functioning of the referral system, prospective payments, and economic prices for all residents. The implementation of the BPJS Law involves PT ASKES, PT ASABRI, PT JAMSOSTEK, and PT TASPEN. Where PT ASKES and PT JAMSOSTEK switch from a Company 
to become a Public Agency starting January 1, 2014. Meanwhile, PT ASABRI and PT TASPEN in 2019 are expected to turn into public bodies by joining BPJS for employment.

BPJS health services have a target in implementing operational sustainability by providing benefits to all those involved in BPJS, meeting the medical needs of participants, and prudence and transparency in BPJS financial management. However, it seems that there are still problems in the implementation of BPJS, some of which are:

1. Health care delivery system

a. The refusal of incapacitated patients in health care facilities is due to PP no. 101/2012 concerning PBI jo. Presidential Decree 111/2013 concerning Health Insurance only accommodates 86.4 million poor people as PBI, whereas according to BPS (2011) there are 96.7 million poor people. The implementation of BPJS in 2014 was supported by funding from the government of Rp. 26 trillion is budgeted in the 2014 RAPBN. The budget is used for Contribution Assistance Recipients (PBI) of Rp. 16.07 trillion for 86.4 million poor people while the rest for civil servants, military, and police. The government should immediately budget for health costs of Rp. 400 billion for the homeless, street children, residents of orphanages, nursing homes, and prison residents (the number is around 1.7 million 
people). And of course, the number of poor people who discover BPJS health must be increased to 96.7 million with the consequence of increasing the budget from the state budget.

b. Implementation in the field, health services provided by PPK I (Puskesmas clinic) and PPK II (Hospitals) are still problematic. Patients have to look for rooms from one hospital to another because it is said to be full of hospitals, this is not a new thing and has only happened once.

2. Payment system (Health Care Payment System)

a. Insufficient funds set by BPJS with real costs, related to financing with the INA CBGs and Capitation schemes which were castrated by Minister of Health Regulation No. 69/2013. The issuance of SE No. 31 and 32 of 2014 by the Minister of Health to strengthen Permenkes No.69 has not been able to reduce problems in the field.

b. Clarity in the area of supervision is still weak, both internally and externally. Internal supervision, such as increasing the number of participants from 20 million (formerly managed by PT Askes) to more than 111 million participants, needs to be anticipated with changes in the system and pattern of supervision so that corruption does not occur. External supervision, through the supervision of the Financial Services Authority (OJK), the National Social 
Security Council (DJSN), and the Financial Supervisory Agency (BPK) is still unclear on the area of supervision

\section{Health Care Quality System}

a. The requirement for national, medium, and small state-owned and private companies to become BPJS Health participants has not been realized considering that the additional benefits received by state-owned or other private workers through derivative regulations have not yet been completed. This is not following the mandate of Presidential Decree No. 111/2013 (articles 24 and 27) regarding the requirement for BUMN and private workers to become BPJS Health participants no later than January 1, 2015. And this additional regulation must be communicated transparently with private health insurance, labor unions, and Apindo so that the issue of additional benefits is no longer a problem.

b. There is still a lack of available health workers in health facilities so that BPJS participants are not handled quickly.

Related to this problem, it is necessary to make synergistic and harmonized efforts between policymakers in formulating comprehensive policies (Ooms et al., 2017). So it is necessary to revise BPJS derivative regulations such as in determining BPJS costs and regulating the distribution of funds to health facilities providers, the number of available health workers (doctors, nurses, hospital administration, and others) to facilitate and improve the 
quality of health services, as well as health facilities that provide health services. owned can support the implementation efficiently and effectively.

The reality on the ground shows that since this program was initiated through the Jamkesmas Program and then continued with BPJS since January 1, 2014, the JKN program has created many problems. Not only complicated and convoluted administration, but also chaotic hospital services, but also many cases of rejection of poor patients. However, the basic problem stems from the technical service, but in the concept that underlies the implementation of this system, namely Law no. 40 of 2004 on SJSN and Law No. 24 of 2011 on BPJS. In the management of the two laws which are directly implemented in the JKN program, it is very clear that the BPJS Law and the SJSN Law are only intended for participants, of course, this violates the 1945 Constitution which requires that social welfare and health services are the rights of all Indonesian citizens.

In addition, SJSN and BPJS are social security for the community, but in the concept of implementing the two, they are not proper social security, but social insurance. Just look at article 1 paragraph 8 of Law No. 40 of 2004 where participants are everyone, including foreigners who have worked for a minimum of 6 months in Indonesia, who have paid dues and also in article 17 paragraph 1 of Law No. 40 of 2004 where each participant 
obliged to pay contributions whose amount has been determined based on a percentage of wages or a certain nominal amount. Only social insurance collects contributions to its participants, so for JKN participants who do not pay contributions, of course, they will not be given social security as they should.

Finally, although there are still many weaknesses in various aspects, changes for changes can be carried out properly and directed to create a comprehensive health social security program and guarantee the rights of all Indonesian people. So that the mandate of the 1945 Constitution as the state constitution can be implemented properly and Indonesia is one step ahead towards prosperity

\section{CHAPTER IV}

\section{A. Conclusion}

Health is a human right as well as an investment for the success of nation-building. For this reason, comprehensive and sustainable health development is carried out, to increase awareness, willingness, and ability to live healthy for everyone to realize the highest degree of public health.

In the SJSN and BPJS Laws, it has been regulated that the government will implement a social security system consisting of National Health Insurance. The law also mandates that the 
Government must establish an Organizing Body to implement a national health insurance program for all Indonesians.

However, in its implementation, various problems give rise to pros and cons, especially related to financing mechanisms and systems. Although, the birth of the BPJS Law is certainly inseparable from its patent law, namely Law no. 40 of 2004 concerning the National Social Security System.

\section{B. Suggestion}

Based on the results of the analysis of the implementation of national health insurance that is currently being implemented as well as various problems that occur related to the fulfillment of community rights in the health sector which cannot be fully accommodated by the state, the government should evaluate the BPJS Law and Law No. 40 of 2004 concerning the Health Insurance System. National Social. The two laws currently being implemented should be based on the 1945 Constitution and should not harm the people. For example, by eliminating the principle of social insurance in BPJS and SJSN, because it is very burdensome for people who still have to pay premiums every month. It also includes the making of derivative policies that appreciate that the social health insurance in Indonesia is right on target and based on the state constitution and the principle of justice for all Indonesian people. 


\section{Reference}

Ackerman, J. M. (2005). Human rights and social accountability. Participation and Civic Engagement, Social Development Department ....

Aravacik, E. D. (2018). Social policy and the welfare state. In Public Economics and Finance. IntechOpen.

Barrientos, A., \& Hulme, D. (2009). Social protection for the poor and poorest in developing countries: reflections on a quiet revolution: commentary. Oxford Development Studies, 37(4), 439-456.

Bintang, S., Mujibussalim, M., \& Fikri, F. (2019).

Decentralization of Indonesia social health insurance.

International Journal of Law and Management.

Chernichovsky, D. (1995). Health system reforms in industrialized democracies: an emerging paradigm. The Milbank Quarterly, 339-372.

de Campos, T. C. (2012). Health as a basic human need: would this be enough? The Journal of Law, Medicine \& Ethics, 40(2), 251-267.

Devereux, S., \& Sabates-Wheeler, R. (2004). Transformative social protection.

Etienne, C., Asamoa-Baah, A., \& Evans, D. B. (2010). Health systems financing: the path to universal coverage. World Health Organization. 
Gostin, L. O., \& Wiley, L. F. (2016). Public health law. University of California Press.

HRW. (1953). Charles E. Merriam, 1874-1953. Social Service Review, 27(2), 218-219.

Hsiao, W. C. L. (1995). The Chinese health care system: lessons for other nations. Social Science \& Medicine, 41(8), 10471055.

Korpi, W. (2001). Contentious institutions: an augmented rational-action analysis of the origins and path dependency of welfare state institutions in Western countries. Rationality and Society, 13(2), 235-283.

Locker, D., \& Dunt, D. (1978). Theoretical and methodological issues in sociological studies of consumer satisfaction with medical care. Social Science \& Medicine. Part A: Medical Psychology \& Medical Sociology, 12, 283-292.

Lönnqvist, A., \& Laihonen, H. (2012). Welfare service system productivity: the concept and its application. International Journal of Productivity and Performance Management. Maeda, A., Araujo, E., Cashin, C., Harris, J., Ikegami, N., \& Reich, M. R. (2014). Universal health coverage for inclusive and sustainable development: a synthesis of 11 country case studies. World Bank Publications. 
Magnussen, L., Ehiri, J., \& Jolly, P. (2004). Comprehensive versus selective primary health care: lessons for global health policy. Health Affairs, 23(3), 167-176.

McIntyre, D., Ranson, M. K., Aulakh, B. K., \& Honda, A. (2013). Promoting universal financial protection: evidence from seven low-and middle-income countries on factors facilitating or hindering progress. Health Research Policy and Systems, 11(1), 1-10.

Meng, Q., Fang, H., Liu, X., Yuan, B., \& Xu, J. (2015).

Consolidating the social health insurance schemes in China: towards an equitable and efficient health system. The Lancet, 386(10002), 1484-1492.

Murphy, J. B. (2008). The Philosophy of Positive Law. Yale University Press.

Ooms, G., Beiersmann, C., Flores, W., Hanefeld, J., Müller, O., Mulumba, M., Ottersen, T., Sarker, M., \& Jahn, A. (2017). Synergies and tensions between universal health coverage and global health security: why we need a second 'Maximizing Positive Synergies' initiative. BMJ Global Health, 2(1), e000217.

Organization, W. H. (2015). Tracking universal health coverage: first global monitoring report. World Health Organization. Outka, G. (1974). Social justice and equal access to health care. The Journal of Religious Ethics, 11-32. 
Ron, A., Abel-Smith, B., \& Tamburi, G. (1990). Health insurance in developing countries: The social security approach (Vol. 34). International Labour Organization.

Ruger, J. P. (2004). Health and social justice. The Lancet, 364(9439), 1075-1080.

Sheikh Hussin, S. A. (2012). Employees Provident Fund (EPF) Malaysia: Generic models for asset and liability management under uncertainty. Brunel University, School of Information Systems, Computing and Mathematics.

Suryawati, N. (2020). Criticize the Constitutional Rights of Citizens on Era and Post Pandemic Covid 19 in State of the Republic of Indonesia.

Tangcharoensathien, V., Patcharanarumol, W., Ir, P., Aljunid, S. M., Mukti, A. G., Akkhavong, K., Banzon, E., Huong, D. B., Thabrany, H., \& Mills, A. (2011). Health-financing reforms in southeast Asia: Challenges in achieving universal coverage. In The Lancet. https://doi.org/10.1016/S01406736(10)61890-9 